\title{
Enantioselective Allene Addition to Aryl and Alkyl Imines
}

Key words

allenes

boron

enantioselectivity

Selected examples:

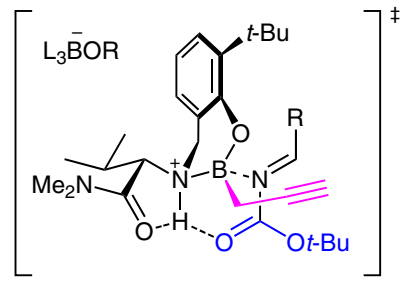<smiles>C=CC(=O)N[C@@H](C=C)c1ccccc1Cl</smiles>

$86 \%$ yield er $=98: 2$<smiles>C=CC(=O)N[C@@H](C=C)c1cccnc1</smiles>

$77 \%$ yield er $=84: 16$<smiles>C=CC(=O)N[C@@H](C=C)c1ccc(OC)cc1</smiles>

\section{$74 \%$ yield}

er $=97: 3$<smiles>[R6]N[C@@H](C=C)CCC=C</smiles>

$80 \%$ yield er $=99: 1$<smiles>C=CC(=O)N[C@@H](C=C)c1ccsc1</smiles><smiles>C=CC(=C)C(=O)N[C@@H](C=C)c1cc2ccccc2o1</smiles>

\section{$88 \%$ yield} er $=97: 3$

$$
\begin{array}{r}
89 \% \text { yield } \\
\text { er }=95: 5
\end{array}
$$<smiles>C=CC(=C)C(=O)OC(C)(C)C</smiles>

$75 \%$ yield er $=99: 1$<smiles>C=CC(=O)NC(C=C)C1CCCCC1</smiles>

\section{$91 \%$ yield} er > 99:1
Significance: Hoveyda and co-workers report a highly efficient method for the enantioselective preparation of aryl-, heteroaryl-, and alkyl-substituted homoallenylamides. The addition of an allenyl unit to various Boc-protected imines proceeds with high yield and very good enantioselectivity.
Comment: The application of this new protocol shows its relevance in the total syntheses of the natural products anisomycin and epi-cytoxazone. Furthermore, it is shown that the allenyl addition performed on gram scale proceeds with high efficiency and selectivity, providing the corresponding product in excellent yield. 